\section{KOMPETENSI, INDEPENDENSI, DAN MOTIVASI SEBAGAI DETERMINAN KINERJA AUDITOR INTERNAL PEMERINTAH}

\author{
Lisa Agustina dan Sulardi \\ Universitas Sebelas Maret \\ J1. Ir. Sutami No.36A, Jebres, Kota Surakarta, Jawa Tengah, Indonesia \\ lisaagustina259@gmail.com
}

JRAK

8,1

35

diterima 05 Maret 2018, direview 08 Maret 2018 direvisi 12 Maret,

diterima 14 Maret 2018.

Artikel ini tersedia di website: http://ejournal.umm.ac.id/index.php/jrak

Doi: 10.22219 /jrak.v8i1.25

\title{
ABSTRACT
}

This research proposes to test and find empirical evidence about the influence of competence, independence, and the motivation of internal government auditor performance. These samples are internal auditor with Functional Auditor (JFA) position and Control Officers (P2UPD) in Inspectorate Klaten Regency. This research used quantitative approach to entire population which is 40 internal auditors. Sampling technique on this research using census with multiple regression analysis method. The result of this research proves that the competence influence both positive and significant to auditors' performance, independence influence both positive and significant to auditors' performance, and motivation influence both positive and significant to auditors' performance. Therefore, local government should provide training in case for increasing competence, encourage auditor's performance by increasing independence, and strengthen motivation so that the internal auditor can take the role and the function as well as possible so the achievement of local government objectives can be implemented accountably.

Keywords: competence, independence, motivation, auditors' performance

\section{PENDAHULUAN}

Dewasa ini, terdapat tuntutan akan pelaksanaan akuntabilitas sektor publik dan transparansi kinerja dalam mewujudkan good governance di Indonesia. Tercapainya akuntabilitas sektor publik menjadi tujuan utama dalam mewujudkan pemerintahan yang lebih baik. Selain itu, Mardiasmo (2005) menyatakan bahwa audit dalam sektor publik menjadi salah satu aspek penting untuk menegakkan dan mewujudkan good governance. Berkaitan dengan asas akuntabilitas dan transparansi tersebut, maka diperlukan pelaksanaan pemeriksaan keuangan daerah yang dimaksudkan agar seluruh sumber daya ekonomi yang dimiliki daerah dapat dimanfaatkan untuk kepentingan publik. Oleh karena itu, penting bagi suatu daerah untuk membentuk lembaga atau satuan pengawas internal yang dinaungi dalam sebuah Organisasi Perangkat Daerah (OPD) yaitu Inspektorat Daerah. Pada hakikatnya, lembaga ini berfungsi sebagai auditor internal pemerintah yang kegiatannya meliputi proses kegiatan audit secara keseluruhan, review, monitoring, evaluasi, pengawasan, serta berkewajiban untuk mempertanggungjawabkannya kepada kepala daerah.

Untuk itu, auditor internal pemerintah yang berperan sebagai ujung tombak dalam pengelolaan dan pengawasan keuangan daerah harus memiliki kemampuan dan keahlian yang memadai sebagaimana diatur dalam standar umum pertama pada Standar Pemeriksaan Keuangan Negara (SPKN) yaitu "Setiap pemeriksa

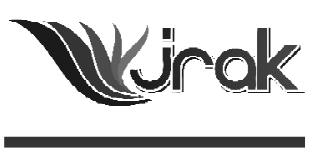

Jurnal Reviu Akuntansi dan Keuangan

p-ISSN : 2615-2223

e-ISSN : 2088-0685

Vol. 8 No. 1, April 2018 
Kompetensi, Independensi, dan Motivasi... 36 atau auditor secara komprehensif wajib mempunyai keahlian yang profesional dan sesuai dalam menjalankan tugasnya sebagai pemeriksa keuangan”. Selain itu, lembaga pemeriksa dan para pemeriksanya memiliki tanggung jawab untuk dapat menjaga independensinya sesuai dengan standar umum kedua yang dijelaskan dalam SPKN yaitu "Terkait segala hal yang berhubungan dengan tugas pemeriksaan maka lembaga pemeriksa dan pemeriksanya harus bebas dalam hal sikap mental dan penampilan dari gangguan internal, eksternal, serta organisasi yang dapat berdampak terhadap independensinya". Selain kedua aspek tersebut, auditor internal juga harus memiliki motivasi yang tinggi untuk terus berprestasi, berkomitmen terhadap kelompok, serta berinisiatif.

Penelitian ini dilakukan di Inspektorat Kabupaten Klaten dikarenakan pengawasan APIP oleh auditor pemerintah sudah dilakukan, namun fakta menunjukkan bahwa tingkat penyimpangan keuangan di Kabupaten Klaten tergolong cukup tinggi. Selain itu, Kabupaten Klaten tengah menjadi sorotan publik terkait kasus korupsi. Hal ini terbukti di akhir tahun 2016 tepatnya 30 Desember 2016 Bupati Klaten ditangkap KPK terkait Operasi Tangkap Tangan (OTT) yang berhubungan dengan suap promosi jabatan dalam pengisian perangkat daerah di Kabupaten Klaten (Jakarta: Solopos- Jumat, 30 Desember 2016). Terkuaknya kasus suap di Pemerintah Kabupaten Klaten yang melibatkan bupati dan beberapa pejabat eselon membuktikan bahwa Klaten termasuk dalam zona merah kasus korupsi serta mengindikasikan bahwa kinerja aparat Inspektorat Kabupaten Klaten masih relatif rendah.

Rendahnya kinerja inspektorat ini dapat dipengaruhi oleh beberapa faktor mulai dari faktor yang berasal dari individu inspektorat dan jajarannya hingga faktor luar yang bersumber dari lingkungan pemerintah daerah. Kurangnya jumlah personel juga menjadi faktor lemahnya kinerja auditor di inspektorat daerah. Di samping itu, kebijakan kepala daerah dapat menjadikan kinerja inspektorat menjadi tidak optimal seperti adanya rotasi jabatan yang tidak sesuai. Masalah rotasi jabatan sering terjadi di pemerintah daerah kabupaten/kota tidak terkecuali pejabat struktural yang menduduki jabatan strategis di lingkungan inspektorat kabupaten/kota yaitu Inspektur, Inspektur Pembantu/Irban, dan Sekretaris.

Dalam hal ini, terkadang auditor pemerintah juga melakukan audit pada OPD yang dipimpin oleh mantan pimpinannya atau rekan sesama auditor yang telah memiliki hubungan interpersonal yang tinggi, baik hubungan kekerabatan maupun relasi kepentingan lainnya. Selain itu, auditor pemerintah di Kabupaten Klaten juga memiliki pengaruh di bawah Bupati. Hal ini dikarenakan seorang inspektur diangkat, diberhentikan, serta memiliki tanggung jawab kepada Bupati melalui Sekda sehingga struktur dan kinerjanya menjadi tidak independen. Ketiadaan independensi menjadikan inspektorat tidak dapat melaksanakan fungsinya secara optimal. Akibatnya permasalahan independensi menjadi hal yang tidak dapat dielakkan bagi auditor di inspektorat daerah.

Oleh karena itu, untuk mewujudkan kinerja yang optimal maka seorang auditor harus berkompeten dalam melaksanakan tugasnya sebagai pengawas dan pemeriksa keuangan di daerah. Akan tetapi, kompetensi yang dimiliki seorang auditor bukan menjadi jaminan untuk berkinerja dengan baik. Selain itu, tidak mudah bagi auditor untuk menjaga independensi dan motivasi karena terdapat tekanan dan tuntutan yang tinggi dari penentu kebijakan yang akan berdampak pada kinerja auditor. Di sisi lain, independensi merupakan komponen yang wajib dimiliki oleh seorang pemeriksa dalam menjalankan fungsi dan perannya sebagai auditor. Motivasi juga sangat diperlukan bagi auditor agar dapat bekerja dengan optimal karena dengan adanya motivasi tersebut akan menimbulkan antusias yang tinggi untuk menjalankan tugasnya secara profesional. Dengan demikian, ketiga komponen tersebut sangat dibutuhkan oleh auditor internal pemerintah untuk 
meningkatkan kinerjanya sebagai penjamin kualitas dalam rangka menyelenggarakan pemerintahan yang transparan dan akuntabel.

Penelitian sebelumnya terkait kinerja auditor telah dilakukan oleh Sujana (2012), Salju dkk. (2014), Sapariyah (2011), dan Arifah (2012). Penelitian Sujana (2012) menunjukkan bahwa kompetensi dan motivasi memengaruhi kinerja auditor secara signifikan. Menurut Salju dkk. (2014) independensi pada auditor pemerintahan tidak memengaruhi kinerja auditor secara signifikan. Selain itu, Sapariyah (2011) menunjukkan bahwa independensi auditor memengaruhi kinerja auditor secara positif tetapi tidak signifikan. Akan tetapi, menurut Arifah (2012) independensi memengaruhi kinerja auditor secara positif dan signifikan. Mengacu pada penelitian-penelitian tersebut, maka peneliti ingin melakukan studi tentang kinerja auditor yang dipengaruhi oleh kompetensi, independensi, dan motivasi karena adanya perbedaan diantara peneliti-peneliti sebelumnya (research gap). Selain itu, penelitian ini juga memiliki perbedaan dengan penelitian terdahulu yaitu dari subjek penelitian, sampel penelitian, lokasi penelitian, hingga variabel penelitian yang digunakan.

Berdasarkan uraian di atas maka penelitian ini penting untuk dilakukan karena auditor pemerintah menjadi garda terdepan yang memiliki peran strategis dalam menjamin kualitas penyelenggaraan pemerintahan. Selain itu, kinerja auditor tengah menjadi isu hangat untuk diperbincangkan oleh berbagai elemen masyarakat. Hal ini dikarenakan banyaknya kepala daerah yang tersandung masalah korupsi sehingga perlu dilakukan pengujian dan pembuktian yang mendalam terkait kinerja auditor pemerintah. Dalam hal ini, penelitian ini dilakukan di Inspektorat Kabupaten Klaten yang belum pernah dilakukan penelitian sebelumnya mengenai kinerja auditor. Dengan pertimbangan tersebut, maka penulis tertarik untuk melakukan penelitian lebih lanjut tentang kompetensi, independensi, dan motivasi sebagai determinan kinerja auditor internal di Kabupaten Klaten.

\section{KAJIAN PUSTAKA}

\section{Teori Harapan (Expectancy Theory)}

Teori harapan atau ekspektasi (expectancy theory) oleh Vroom (1964) menyatakan bahwa seseorang akan bertindak untuk memperoleh hasil atau memaksimalkan kepuasan yang diharapkan. Hal ini akan memunculkan motivasi dalam diri seseorang yang akan mendorong untuk melakukan kinerja yang terbaik demi memperoleh hasil yang diharapkan. Menurut teori ini dapat dijelaskan bahwa kecenderungan yang dilakukan seseorang untuk bertindak dengan menggunakan cara apapun dipengaruhi oleh adanya harapan bahwa kinerja akan diimbangi dengan output yang pasti.

Teori ini juga sangat berkaitan dengan motivasi yang merupakan kekuatan dalam diri individu untuk mengarahkan pada suatu usaha yang akan memengaruhi pada kinerja seseorang. Namun, usaha saja tidak cukup untuk mengarahkan pada kinerja yang terbaik sehingga diperlukan kemampuan (ability) yang sesuai sehingga dapat tercipta kinerja yang optimal. Berkaitan dengan kinerja auditor maka kompetensi dan motivasi dapat mendorong seorang auditor untuk mengeluarkan seluruh kemampuan terbaiknya untuk memperoleh penghargaan atas kinerja yang telah dilakukannya.

Selain itu, faktor lain yang dapat berpengaruh terhadap kinerja auditor inspektorat yaitu adanya sikap independensi. Hal ini dikarenakan independensi merupakan minimum requirement yang harus dimiliki oleh seorang auditor sehingga dengan adanya sikap tersebut maka kinerja auditor inspektorat tidak dira- 
Kompetensi, Independensi, dan Motivasi... 38 gukan lagi. Dengan demikian, teori harapan sangat tepat digunakan dalam penelitian ini dikarenakan sesuai dengan variabel yang akan diteliti.

\section{Auditor Internal}

Mulyadi (1992) menjelaskan bahwa audit intern merupakan auditor di dalam perusahaan yang memiliki pekerjaan untuk mengetahui apakah kebijakan serta prosedur yang telah ditentukan oleh manajemen tertinggi sudah ditaati atau belum, menentukan apakah perusahaan telah menjaga kekayaan organisasi dengan baik atau tidak, menentukan apakah prosedur kegiatan organisasi telah dijalankan secara efisien dan efektif, serta menentukan apakah informasi yang didapatkan oleh beberapa elemen organisasi sudah handal atau belum. Dalam hal ini, lembaga yang terdapat dalam tubuh pemerintah yang memiliki fungsi dan tugas untuk melaksanakan pemeriksaan dan pengawasan secara fungsional adalah Aparat Pengawasan Intern Pemerintah (APIP). Berkaitan dengan hal tersebut, maka lembaga yang ditunjuk oleh pemerintah untuk menjalankan perannya sebagai auditor internal di pemerintah daerah adalah Inspektorat Daerah yang memiliki kewenangan, fungsi, dan tugas yang harus dijalankan dengan penuh tanggung jawab dan berdedikasi tinggi dalam pekerjaannya.

\section{Kinerja auditor}

Kinerja auditor adalah suatu perbuatan untuk melaksanakan perannya sebagai pemeriksa keuangan yang sudah dikerjakan oleh auditor dalam kurun waktu tertentu. Trisnaningsih (2007) mengemukakan bahwa penilaian kinerja dapat dinilai melalui standar tertentu yaitu dari aspek kualitas, kuantitas, dan ketepatan waktu. Dalam hal ini kualitas berhubungan dengan mutu kerja yang dapat dicapai sedangkan kuantitas berhubungan dengan jumlah hasil kerja yang dapat dicapai oleh auditor dalam jangka waktu tertentu.

\section{Kompetensi}

Jusup (2001) menyatakan bahwa kompetensi merupakan pencapaian dan pemeliharaan suatu tingkatan pemahaman dan pengetahuan yang memungkinkan seorang auditor untuk memberikan jasa dengan kemudahan dan kecerdikan. Selain itu, Standar Pemeriksaan Keuangan Negara terkait standar umum pertama mengemukakan bahwa seorang auditor wajib memiliki kecakapan profesional serta memadai dalam melakukan tugasnya sebagai pemeriksa keuangan. Seorang pemeriksa belum dapat dikatakan mumpuni atau profesional di bidangnya apabila tidak mempunyai pendidikan atau pengalaman sama sekali dalam bidang audit dan pemerintahan. Oleh karena itu, penting bagi auditor untuk terus mengasah kemampuan dan keahliannya dalam berbagai aspek terutama yang berkaitan dengan pemerintahan serta teknik ataupun metode dalam pengauditan.

Pegawai yang berkompeten dalam menjalankan tugasnya akan dapat memahami apa sebenarnya fungsi dirinya menjadi auditor. Semakin tinggi kompetensi yang ada pada diri seorang auditor maka kinerjanya juga akan semakin tinggi. Hal ini dikarenakan auditor yang kompeten dan berpengalaman akan mengetahui beraneka ragam penemuan, permasalahan, dan penyimpangan yang terjadi ketika melakukan pemeriksaan di lapangan sehingga auditor dapat mengatasi permasalahan yang ada dengan bijak dan mampu memberikan solusi yang terbaik dari masalah tersebut. Akan tetapi, auditor yang tidak memiliki kompetensi yang memadai dapat menyebabkan kekeliruan yang lebih tinggi jika dibandingkan dengan auditor yang telah mempunyai banyak pengalaman dan berkompeten di bidangnya.

\section{Independensi}

Menurut Arens et.al. (2008), auditor bukan hanya harus independen dalam hal fakta saja, akan tetapi juga harus independen dalam segi penampilan. Mulyadi 
(1992) juga mendefinisikan bahwa independensi sebagai sebuah kejujuran yang ada pada diri seorang akuntan untuk selalu memperhitungkan fakta dan pertimbangan objektif serta tidak memihak selama mengungkapkan pendapatnya dalam melaksanakan proses audit.

\section{Motivasi}

Motivasi merupakan pemberian daya penggerak yang menciptakan kegairahan kerja seseorang agar mereka mau bekerja sama, bekerja efektif, dan terintegrasi dengan segala daya dan upayanya untuk mencapai kepuasan (Hasibuan, 2010). Terdapat hubungan yang searah antara motivasi dengan kinerja artinya ketika seseorang memiliki motivasi yang tinggi maka secara langsung kinerjanya akan semakin tinggi pula.

\section{PENGEMBANGAN HIPOTESIS}

\section{Pengaruh Kompetensi terhadap Kinerja Auditor}

Kompetensi auditor adalah kapabilitas yang dimiliki auditor untuk menerapkan pengetahuan dan pengalamannya untuk dapat melakukan audit dengan lebih teliti, penuh kecermatan, berjiwa intuitif, serta objektif (Efendy, 2010). Berdasarkan teori harapan, kompetensi merupakan salah satu komponen yang harus dimiliki oleh auditor untuk mengarahkan pada kinerja yang terbaik sehingga dapat tercipta kinerja yang optimal. Auditor yang mempunyai kompetensi yang tinggi dan sesuai akan lebih memahami dan mampu mengerjakan tugas-tugasnya dengan penuh rasa tanggung jawab. Akan tetapi, apabila auditor tidak memiliki kompetensi dalam bidang audit maupun pemerintahan maka auditor akan lebih banyak melakukan atribusi kesalahan dalam menjalankan tugasnya sehingga kinerjanya tidak optimal dan hasil audit menjadi tidak berkualitas. Menurut penelitian Sujana (2012) menunjukkan bahwa kompetensi memengaruhi kinerja auditor secara signifikan, sedangkan penelitian dari Salju dkk. (2014) menunjukkan bahwa kompetensi tidak memengaruhi kinerja auditor pemerintah daerah secara signifikan.

Dari studi yang telah dilakukan oleh Sujana (2012) didapatkan hasil bahwa kompetensi memengaruhi kinerja auditor secara signifikan. Selain itu, berdasarkan penelitiannya, Salju dkk. (2014) menyatakan bahwa kompetensi tidak memengaruhi kinerja auditor pemerintah daerah secara signifikan. Hasil ini berbeda dengan studi yang dilakukan oleh Efendy (2010) yang membuktikan bahwa kompetensi memengaruhi kualitas audit secara signifikan.

Berdasarkan penjabaran di atas, maka dapat dikembangkan hipotesis seperti berikut ini.

$\mathrm{H}_{1}$. Kompetensi berpengaruh positif terhadap kinerja auditor Inspektorat.

\section{Pengaruh Independensi terhadap Kinerja Auditor}

Mulyadi (1992) mendefinisikan independensi sebagai sebuah kejujuran yang ada pada diri seorang akuntan untuk selalu mempertimbangkan fakta dan pertimbangan objektif serta tidak memihak untuk merumuskan dan mengungkapkan pendapatnya dalam melaksanakan proses audit. Berdasarkan teori harapan, independensi merupakan persyaratan minimal yang harus dimiliki oleh seorang auditor dalam menjalankan tugasnya sebagai pemeriksa dan pengawasan keuangan di daerah sehingga dengan adanya independensi tersebut kinerja auditor tidak diragukan lagi oleh stakeholders. Semakin tinggi independensi yang dimiliki auditor maka hasil pemeriksaannya akan sesuai dengan fakta-fakta yang ada sehingga kinerja auditor diharapkan akan semakin baik. Selain itu, auditor yang selalu menegakkan independensi dalam pekerjaannya maka tidak akan terpengaruh dan tidak dapat dipengaruhi oleh faktor-faktor yang dapat dijumpainya 
Kompetensi, Independensi, dan Motivasi... ketika melakukan pemeriksaan. Akibatnya auditor dapat berkinerja secara maksimal dengan tetap berlandaskan pada standar etika yang telah ditetapkan oleh profesinya. Menurut penelitian Arifah (2012) menunjukkan bahwa independensi auditor memengaruhi kinerja auditor secara positif dan signifikan. Berlawanan dengan hasil dari penelitian Salju dkk. (2014) yang menunjukkan bahwa independensi auditor pemerintahan tidak memengaruhi kinerja auditor secara signifikan.

Berdasarkan penelitian oleh Salju dkk. (2014), independensi auditor pemerintahan tidak memengaruhi kinerja auditor secara signifikan. Selain itu, dari penelitian yang dilakukan Sapariyah (2011) yang berjudul pengaruh good governance dan independensi auditor terhadap kinerja auditor dan komitmen organisasi dapat dijelaskan bahwa independensi auditor memengaruhi secara positif tetapi tidak signifikan terhadap kinerja auditor. Sementara Arifah (2012) melakukan penelitian tentang pengaruh independensi auditor, komitmen organisasi, dan gaya kepemimpinan yang didapatkan hasil bahwa independensi auditor memengaruhi kinerja auditor secara positif dan signifikan.

Berdasarkan penjabaran di atas, maka dapat dikembangkan hipotesis seperti berikut ini.

$\mathrm{H}_{2}$. Independensi berpengaruh positif terhadap kinerja auditor Inspektorat.

\section{Pengaruh Motivasi terhadap Kinerja Auditor}

Motivasi diperlukan oleh auditor untuk terus berprestasi, berkomitmen terhadap kelompok, serta berinisiatif dalam rangka meningkatkan produktivitas dan etos kerja (Efendy, 2010). Berdasarkan teori harapan, motivasi merupakan kekuatan dalam diri individu untuk mengarahkan pada suatu usaha yang akan memengaruhi pada kinerja auditor. Auditor yang memiliki motivasi dan dorongan yang tinggi dalam pekerjaannya akan mengerahkan segala upaya yang dimilikinya secara maksimal agar tujuan yang telah ditetapkan dapat tercapai dan kinerjanya menjadi optimal. Menurut penelitian Respatiningsih dan Sudirjo (2015) menunjukkan bahwa motivasi memengaruhi kinerja pegawai secara positif dan signifikan sedangkan penelitian dari Brahmasari dan Suprayetno (2008) menunjukkan bahwa motivasi tidak memengaruhi kinerja perusahaan secara signifikan.

Berdasarkan penjabaran di atas, maka dapat dikembangkan hipotesis seperti berikut ini.

$\mathrm{H}_{3}$. Motivasi berpengaruh positif terhadap kinerja auditor Inspektorat.

\section{METODE}

\section{Populasi, Sampel, dan Teknik Pengambilan Sampel}

Dalam studi ini penulis mengambil populasi secara keseluruhan yaitu auditor pemerintah di Inspektorat Kabupaten Klaten sebanyak 40 orang. Penelitian ini dilaksanakan di Inspektorat Kabupaten Klaten pada bulan Desember 2017. Pengambilan lokasi dalam penelitian ini di Kabupaten Klaten dikarenakan kinerja auditor di Inspektorat Kabupaten Klaten tengah menjadi pusat perhatian oleh masyarakat sekitar karena adanya penangkapan Bupati Klaten oleh KPK terkait suap dalam pengisian perangkat daerah. Kuesioner yang diserahkan kepada responden adalah sebanyak jumlah populasi dalam penelitian ini yaitu 40 kuesioner. Metode yang dipakai untuk memilih sampel dalam penelitian ini adalah metode sensus yaitu kuesioner disebarkan pada semua populasi yang ada.

\section{Desain Penelitian, Jenis, dan Metode Pengumpulan Data}

Penelitian ini merupakan tipe penelitian penjelasan. Hal ini dikarenakan penelitian ini bertujuan untuk menerangkan hubungan di antara variabel-variabel 
melalui pengujian suatu hipotesis yang sudah dirumuskan dalam suatu penelitian. Data dalam penelitian ini merupakan data primer dengan menggunakan kuesioner yang berbentuk pernyataan positif dan negatif. Unit analisis dari penelitian ini adalah perilaku auditor di Inspektorat Kabupaten Klaten. Metode utama dalam penelitian ini adalah penelitian survey. Penyebaran kuisioner dilaksanakan dengan cara mendatangi langsung ke inspektorat yang akan diteliti.

Instrumen yang digunakan dalam penelitian ini adalah instrumen kuesioner untuk Kompetensi, Independensi, Motivasi, dan Kinerja Auditor. Penelitian ini menggunakan instrumen kuesioner yang diadaptasi dari penelitian yang dilakukan oleh Effendy (2010) dan Nuraini (2016) yang telah teruji secara validitas dan reliabilitas. Selain itu, setiap konstruk pertanyaan diberi skor menggunakan skala likert 1-5 untuk mengukur jawaban dari responden berupa pernyataan sangat tidak setuju, tidak setuju, netral, setuju, dan sangat setuju. Beberapa indikator pengukurannya adalah sebagai berikut ini.

\begin{tabular}{|c|c|c|}
\hline Dimensi & Indikator & Skala \\
\hline $\begin{array}{l}\text { 1. Penguasaan } \\
\text { Standar } \\
\text { Akuntansi dan } \\
\text { Audit }\end{array}$ & $\begin{array}{l}\text { 1. Saya memahami audit sesuai dengan } \\
\text { standar akuntansi dan audit yang berlaku. } \\
\text { 2. Saya mampu melakukan audit sesuai } \\
\text { dengan standar akuntansi dan audit yang } \\
\text { berlaku. }\end{array}$ & Likert \\
\hline $\begin{array}{c}\text { 2. Wawasan tentang } \\
\text { Pemerintahan }\end{array}$ & $\begin{array}{l}\text { 1. Saya memahami hal-hal terkait struktur } \\
\text { organisasi di pemerintahan. } \\
\text { 2. Saya memahami hal-hal terkait fungsi di } \\
\text { pemerintahan. } \\
\text { 3. Saya memahami hal-hal terkait kegiatan } \\
\text { di pemerintahan. }\end{array}$ & Likert \\
\hline $\begin{array}{l}\text { 3. Peningkatan } \\
\text { Kinerja }\end{array}$ & $\begin{array}{l}\text { 1. Seiring bertambahnya masa kerja saya } \\
\text { sebagai auditor, kinerja audit saya pun } \\
\text { makin bertambah. } \\
\text { 2. Saya sering mengikuti pelatihan } \\
\text { akuntansi dan audit yang diselenggarakan } \\
\text { internal inspektorat untuk peningkatan } \\
\text { kinerja dalam pemeriksaan keuangan di } \\
\text { daerah. } \\
\text { 3. Saya berusaha meningkatkan penguasaan } \\
\text { akuntansi dan audit dengan membaca } \\
\text { literatur sehingga dapat meningkatkan } \\
\text { kinerja. } \\
\text { 4. Saya berusaha meningkatkan penguasaan } \\
\text { akuntansi dan audit dengan mengikuti } \\
\text { pelatihan di luar lingkungan inspektorat } \\
\text { sehingga dapat meningkatkan kinerja. }\end{array}$ & Likert \\
\hline
\end{tabular}

Tabel 1.

Kompetensi Auditor

Pengukuran independensi auditor disajikan pada tabel 2 berikut:

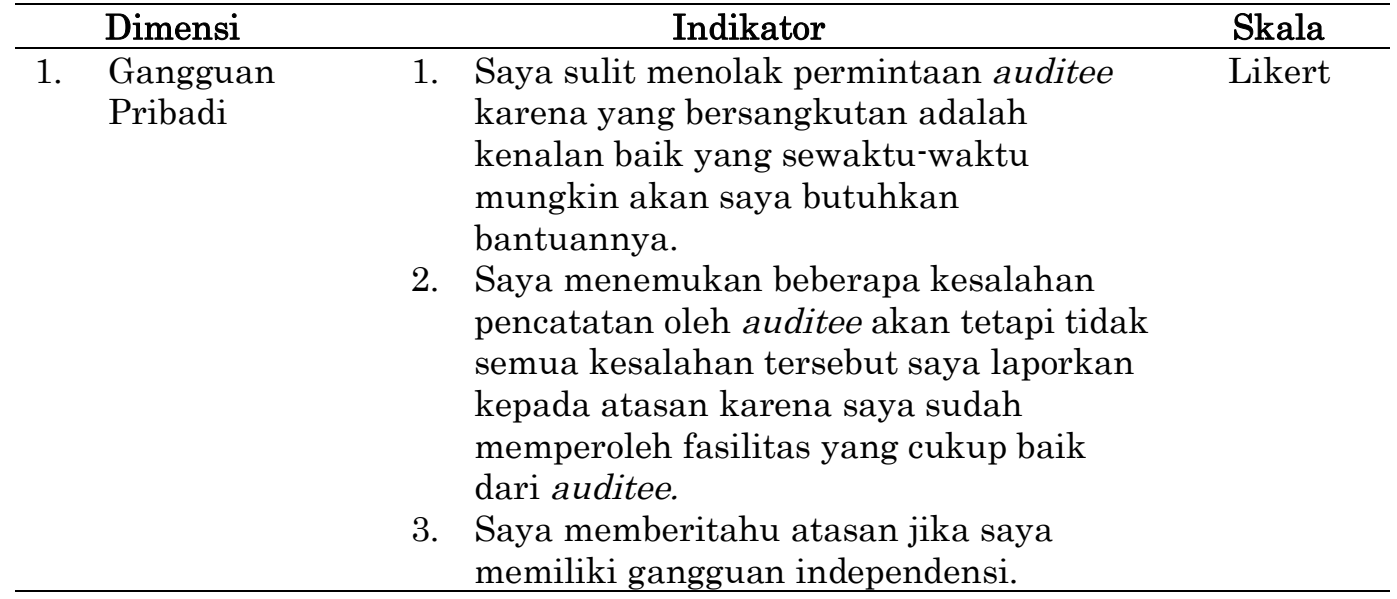


Kompetensi, Independensi, dan Motivasi...

Tabel 2 .

Independensi Auditor

Tabel 3 .

Motivasi Auditor

Tabel 4.

Kinerja Auditor
2. Gangguan

Ekstern

1. Saya tidak peduli apakah saya akan

Likert dimutasi karena mengungkapkan temuan apa adanya.

2. Saya tidak melakukan audit dengan sungguh-sungguh karena ada pihak yang berwenang untuk menolak pertimbangan yang saya berikan pada laporan audit.

Pengukuran motivasi auditor disajikan pada tabel 2 berikut:

\begin{tabular}{|c|c|c|}
\hline Dimensi & Indikator & Skala \\
\hline $\begin{array}{l}\text { 1. Tingkat } \\
\text { Aspirasi: } \\
\text { Urgensi } \\
\text { Audit yang } \\
\text { Berkualitas }\end{array}$ & $\begin{array}{l}\text { 1. Tanpa auditor internal, sebenarnya } \\
\text { pemerintahan sudah bisa berjalan } \\
\text { dengan baik. } \\
\text { 2. Saya akan menerima dampak negatif } \\
\text { jika tidak melakukan audit dengan } \\
\text { baik. }\end{array}$ & Likert \\
\hline 2. Keuletan & $\begin{array}{l}\text { 1. Saya tidak perlu memperbaiki diri } \\
\text { karena yang saya lakukan sudah cukup } \\
\text { baik. }\end{array}$ & Likert \\
\hline
\end{tabular}

Pengukuran kinerja auditor disajikan pada tabel 4 berikut:

\begin{tabular}{|c|c|c|}
\hline Dimensi & Indikator & Skala \\
\hline 1. Komunikasi & $\begin{array}{l}\text { 1. Saya melakukan komunikasi dengan } \\
\text { rekan kerja yang berkaitan dengan } \\
\text { adanya permasalahan dalam audit. }\end{array}$ & Likert \\
\hline $\begin{array}{l}\text { 2. Kualitas } \\
\text { Hasil Kerja }\end{array}$ & $\begin{array}{l}\text { 1. Saya melaksanakan setiap tugas kerja } \\
\text { sesuai dengan jadwal dan prioritas kerja } \\
\text { yang sudah direncanakan. } \\
\text { 2. Saya melaksanakan perintah kerja } \\
\text { sesuai dengan petunjuk atau peraturan } \\
\text { kerja dengan tertib. }\end{array}$ & Likert \\
\hline $\begin{array}{l}\text { 3. Ketepatan } \\
\text { Waktu }\end{array}$ & $\begin{array}{l}\text { 1. Saya mengerjakan tugas dengan tepat } \\
\text { waktu. }\end{array}$ & Likert \\
\hline 4. Kemampuan & $\begin{array}{l}\text { 1. Saya menggunakan keahlian dan } \\
\text { keterampilan sesuai dengan standar } \\
\text { akuntansi dan audit yang berlaku. }\end{array}$ & Likert \\
\hline
\end{tabular}

Analisis data dilakukan dengan 2 tahapan yaitu uji instrumen dan uji kualitas data.

\section{Uji Instrumen}

Penelitian ini menggunakan uji pilot sebanyak 10 responden di Kantor Inspektorat Kabupaten Klaten untuk dilakukan uji pendahuluan sebelum penyebaran kuesioner secara keseluruhan. Selanjutnya kuesioner diolah menggunakan SPSS 21 yang menunjukkan bahwa setiap indikator telah teruji secara validitas dan reliabilitas. Dalam hal ini tidak ada pemisahan responden antara uji pilot dengan uji utamanya.

\section{Uji Kualitas Data Uji Validitas}

Berdasarkan pengujian yang telah dilakukan dapat diambil keputusan bahwa koefisien korelasi untuk setiap item dalam butir pernyataan dengan skor keseluruhan untuk semua variabel adalah signifikan pada tingkat signifikansi di bawah 0,05 dan dapat diartikan bahwa keseluruhan dalam pernyataan tersebut adalah valid. 


\begin{tabular}{ccccc}
\hline Pernyataan & $\begin{array}{c}\text { Pearson Correlation } \\
(\mathbf{r} \text { hitung) }\end{array}$ & $\mathbf{r}$ tabel & Significant & Keterangan \\
\hline Kompetensi 1 & $0,664^{* *}$ & 0,316 & 0,000 & Valid \\
Kompetensi 2 & $0,726^{* *}$ & 0,316 & 0,000 & Valid \\
Kompetensi 3 & $0,635^{* *}$ & 0,316 & 0,000 & Valid \\
Kompetensi 4 & $0,673^{* *}$ & 0,316 & 0,000 & Valid \\
Kompetensi 5 & $0,726^{* *}$ & 0,316 & 0,000 & Valid \\
Kompetensi 6 & $0,463^{* *}$ & 0,316 & 0,003 & Valid \\
Kompetensi 7 & $0,546^{* *}$ & 0,316 & 0,000 & Valid \\
Kompetensi 8 & $0,495^{* *}$ & 0,316 & 0,001 & Valid \\
Kompetensi 9 & $0,369^{*}$ & 0,316 & 0,021 & Valid \\
\hline
\end{tabular}

Tabel 5 .

Hasil Uji Validitas

Variabel Kompetensi $\left(\mathrm{X}_{1}\right)$

Hasil uji validitas variabel independensi disajikan pada tabel 6 berikut

\begin{tabular}{ccccc}
\hline Pernyataan & $\begin{array}{c}\text { Pearson Correlation } \\
\text { (r hitung) }\end{array}$ & r tabel & Significant & Keterangan \\
\hline Independensi 1 & $0,698^{* *}$ & 0,316 & 0,000 & Valid \\
Independensi 2 & $0,665^{* *}$ & 0,316 & 0,000 & Valid \\
Independensi 3 & $0,578^{* *}$ & 0,316 & 0,000 & Valid \\
Independensi 4 & $0,593^{* *}$ & 0,316 & 0,000 & Valid \\
Independensi 5 & $0,654^{* *}$ & 0,316 & 0,000 & Valid \\
\hline
\end{tabular}

Tabel 6.

Hasil Uji Validitas

Variabel

Independensi $\left(\mathrm{X}_{2}\right)$

Hasil uji validitas variabel motivasi disajikan pada tabel 7 berikut:

\begin{tabular}{ccccc}
\hline Pernyataan & $\begin{array}{c}\text { Pearson Correlation } \\
\text { (r hitung) }\end{array}$ & r tabel & Significant & Keterangan \\
\hline Motivasi 1 & $0,653^{* *}$ & 0,316 & 0,000 & Valid \\
Motivasi 2 & $0,762^{* *}$ & 0,316 & 0,000 & Valid \\
Motivasi 3 & $0,688^{* *}$ & 0,316 & 0,000 & Valid \\
\hline
\end{tabular}

Hasil uji validitas variabel kinerja auditor disajikan pada tabel 8 berikut:

\begin{tabular}{ccccc}
\hline Pernyataan & $\begin{array}{c}\text { Pearson Correlation } \\
\text { (r hitung) }\end{array}$ & r tabel & Significant & Keterangan \\
\hline Kinerja Auditor 1 & $0,789 * *$ & 0,316 & 0,000 & Valid \\
Kinerja Auditor 2 & $0,752^{* *}$ & 0,316 & 0,000 & Valid \\
Kinerja Auditor 3 & $0,841^{* *}$ & 0,316 & 0,000 & Valid \\
Kinerja Auditor 4 & $0,781 * *$ & 0,316 & 0,000 & Valid \\
Kinerja Auditor 5 & $0,831^{* *}$ & 0,316 & 0,000 & Valid \\
\hline
\end{tabular}

\section{Uji Reliabilitas}

Hasul uji realibilitas disajikan pada tabel 9 berikut:

\begin{tabular}{lccc}
\hline \multicolumn{1}{c}{ Variabel } & $\begin{array}{c}\text { Cronbach's Alpha Based on } \\
\text { Standardized }\end{array}$ & Kriteria & Keterangan \\
\hline Kompetensi & 0,763 & 0,60 & Reliabel \\
Independensi & 0,644 & 0,60 & Reliabel \\
Motivasi & 0,665 & 0,60 & Reliabel \\
Kinerja Auditor & 0,855 & 0,60 & Reliabel \\
\hline
\end{tabular}

Tabel 9.

Hasil Uji Reliabilitas
Hasil Uji Validitas

Variabel Kinerja

Auditor (Y)

Tabel 9 menerangkan bahwa semua variabel yang menjadi instrumen dalam penelitian ini adalah reliabel. Hal tersebut didukung dengan bukti bahwa Cronbach Alpha $(\alpha)>0,60$ sehingga dapat ditarik kesimpulan bahwa instrumen kuesioner yang digunakan adalah handal dan sesuai dengan uji kualitas data yaitu reliabilitas. 
Kompetensi, Independensi, dan Motivasi...

Gambar 1 . Model Penelitian

\section{Model Penelitian} berikut:

Berdasarkan penjabaran di atas maka model dari penelitian ini adalah sebaai

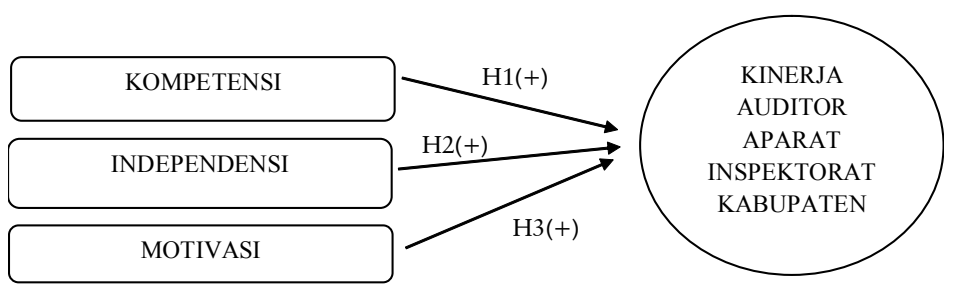

Penelitian ini menggunakan uji regresi berganda dengan persamaan regresinya adalah sebagai berikut ini.

$\mathrm{Y}=\beta_{0}+\beta_{1} \mathrm{X}_{1}+\beta_{2} \mathrm{X}_{2}+\beta_{3} \mathrm{X}_{3}$

Keterangan:

$\mathrm{Y}=$ kinerja auditor Inspektorat,

$\beta_{0}=$ intersep,

$\beta_{1}, \beta_{2}, \beta_{3}=$ koefisien regresi,

$\mathrm{X}_{1}=$ kompetensi,

$\mathrm{X}_{2}=$ independensi, dan

$\mathrm{X}_{3}=$ motivasi.

\section{Teknik Analisis}

Pada penelitian ini penulis menggunakan metode analisis regresi berganda. Pengujian instrumen penelitian dilakukan terlebih dahulu yaitu pengukuran kualitas data melalui uji validitas dan reliabilitas. Selain itu, uji asumsi klasik terdiri dari uji normalitas, uji multikolinearitas, dan uji heteroskedastisitas. Setelah itu, dilanjutkan dengan pengujian hipotesis menggunakan koefisien determinasi $\left(\mathrm{R}^{2}\right)$, uji simultan (Uji F), dan uji parsial (uji t).

\section{HASIL DAN PEMBAHASAN}

\section{Gambaran Umum Responden}

Data dalam penelitian ini merupakan data primer yaitu menggunakan daftar pernyataan (kuesioner). Kuesioner tersebut dibagikan secara langsung kepada auditor Inspektorat Kabupaten Klaten pada hari Senin tanggal 18 Desember 2017. Gambaran umum sampel dapat dilihat pada tabel 10 sebagai berikut ini.

\begin{tabular}{lr}
\hline Total kuesioner yang telah diserahkan & 40 \\
Total kuesioner yang kembali & 40 \\
Tingkat pengembalian & $100 \%$ \\
Total kuesioner yang tidak bisa diolah & 1 \\
Total kuesioner yang bisa diolah & 39 \\
\hline
\end{tabular}

Teknik pembagian kuesioner dilakukan dengan cara memberikan kuesioner kepada seluruh auditor yang terlibat dalam pemeriksaan yaitu sebanyak 40 orang. Kuesioner dapat terkumpul secara keseluruhan yaitu pada hari Senin tanggal 25 Desember 2017 setelah 1 minggu dari penyebaran awal. Tingkat pengembalian (response rate) yang didapatkan adalah 100\%. Hal ini dikarenakan keseluruhan auditor memiliki antusias yang tinggi dan bersedia untuk mengisi kuesioner yang telah dibagikan oleh peneliti. 
Hasil uji normalitas disajikan pada tabel 11 berikut:

\begin{tabular}{llr}
\hline & & Unstandardized Residual \\
\hline $\mathrm{N}$ & & 39 \\
Normal Parameters ${ }^{a, b}$ & Mean &, 0000000 \\
& $\begin{array}{l}\text { Std. } \\
\text { Deviation }\end{array}$ & 1,12298635 \\
Most Extreme & Absolute &, 106 \\
Differences & Positive &, 073 \\
& Negative &,- 106 \\
Kolmogorov-Smirnov $Z$ & &, 664 \\
Asymp. Sig. (2-tailed) & &, 770 \\
\hline
\end{tabular}

Tabel 11 menunjukkan bahwa data dari penelitian ini terdistribusi secara normal. Hal ini sesuai dengan Uji One-Sample Kolmologorov-Smirnov yang menunjukkan nilai 0,664 dan tidak signifikan pada 0,05. Selain itu, nilai Asymp. Sig. (2tailed) adalah 0,770 dan lebih besar dari tingkat signifikansi 0,05. Hasil ini menunjukkan bahwa data tersebar secara normal dan sesuai dengan asumsi normalitas.

Dalam membuktikan normalitas dapat dilihat juga melalui grafik histogram dan grafik normal P-plot untuk mendapatkan hasil yang komprehensif selain melalui uji statistik One-Sample Kolmologorov-Smirnov. Gambar 2 terkait grafik histogram menunjukkan bahwa sumbu telah menyebar di sekitar garis diagonal yang dapat diartikan bahwa pola terdistribusi secara normal dan sesuai dengan asumsi normalitas.

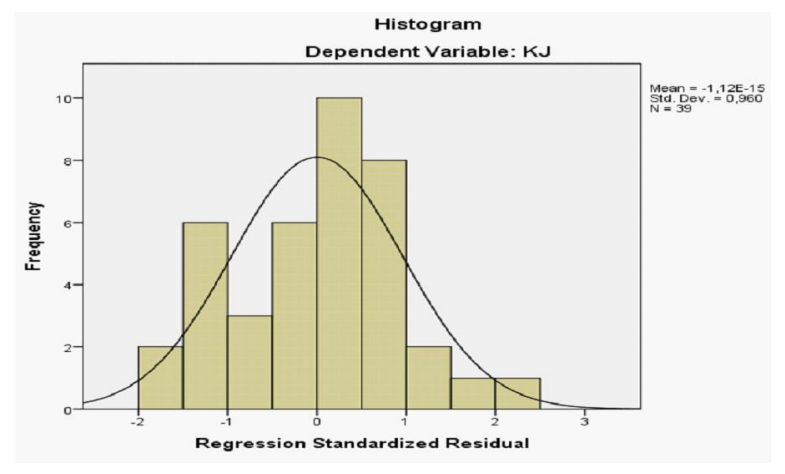

Gambar 2 .

Grafik Histogram

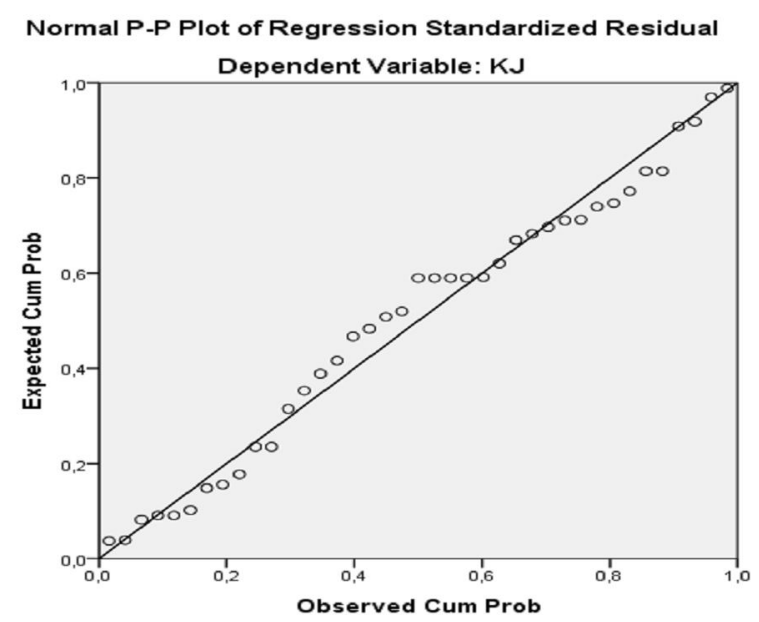

Tabel 11.

Hasil Uji Normalitas

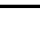


Kompetensi, Independensi, dan Motivasi...

Tabel 12

Hasil Uji

Multikolinieritas

Gambar 4 .

Grafik Scatterplot

Gambar 3 juga dapat dijadikan dasar untuk memberikan hasil apakah data terdistribusi secara normal atau tidak. Gambar di atas menunjukkan bahwa semua titik menyebar di area garis diagonal dan arahnya mengikuti garis diagonal sehingga dapat diinterpretasikan bahwa pola dalam data tersebut terdistribusi secara normal.

\section{Uji Multikolinieritas}

Pengujian ini memiliki tujuan untuk menentukan apakah di dalam suatu model regresi tersebut ditemukan adanya korelasi antara variabel independen. Hal ini dapat diketahui dari nilai tolerance dan Variance Inflation Factor (VIF). Apabila nilai tolerance $>0,1$ dan VIF $<10$, maka dapat disimpulkan bahwa tidak terjadi korelasi antara variabel independen (Ghozali, 2006). Berikut ini hasil uji multikolinieritas pada tabel 12 .

Berdasarkan tabel 12 dapat dijelaskan bahwa variabel kompetensi, independensi, dan motivasi mempunyai nilai tolerance yang lebih besar dari 0,10 yang mengindikasikan bahwa tidak terjadi korelasi antara variabel independen. Selain itu, nilai Variance Inflantion Factor (VIF) untuk semua variabel tidak ada yang melebihi 10. Oleh karena itu, dapat ditarik kesimpulan bahwa tidak terjadi multikolinieritas antara variabel independen di dalam model regresi tersebut.

\section{Uji Heteroskedastisitas}

Uji heterokedastisitas memiliki tujuan untuk meneliti apakah dalam sebuah model regresi terjadi perbedaan varian dari residual antara satu pengamatan dengan pengamatan yang lain.

Gambar 4 menunjukkan bahwa data tersebut membentuk pola yang tidak jelas dan keseluruhan titik yang ada menyebar di atas dan di bawah angka 0 pada sumbu Y. Uji ini juga diperkuat dengan menggunakan uji Glesjer. Tabel 913 mengenai hasil uji Glesjer didapatkan hasil bahwa tingkat signifikansi semua

\begin{tabular}{lccl}
\hline Model & \multicolumn{2}{c}{ Collinearity Statistics } & \multicolumn{1}{c}{ Keputusan } \\
& Tolerance & VIF & \\
\hline 1 (Constant) &, 623 & 1,605 & $\begin{array}{l}\text { Tidak ada } \\
\text { multikolinearitas }\end{array}$ \\
Indempetensi &, 488 & 2,050 & $\begin{array}{l}\text { Tidak ada } \\
\text { multikolinearitas }\end{array}$ \\
Motivasi &, 597 & 1,674 & $\begin{array}{l}\text { Tidak ada } \\
\text { multikolinearitas }\end{array}$ \\
\hline
\end{tabular}

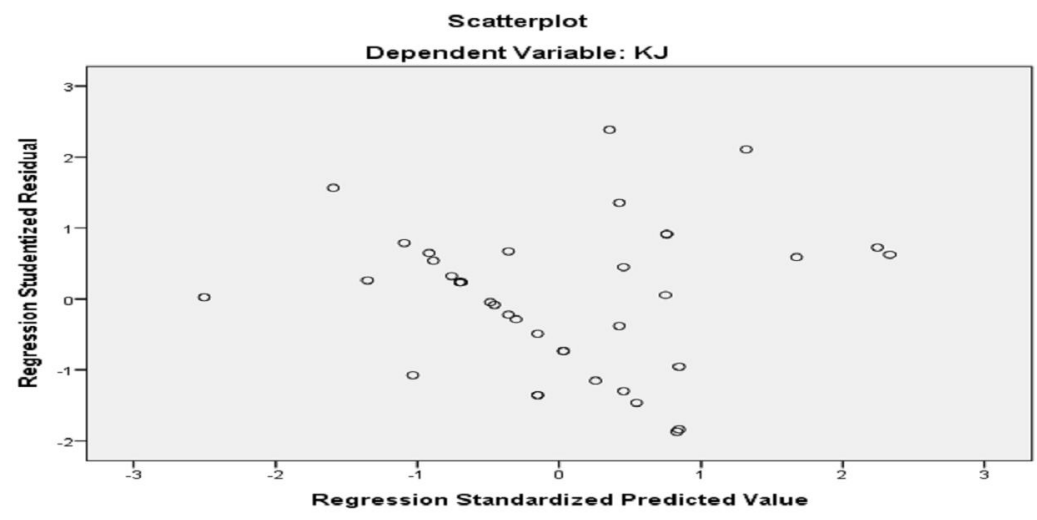


variabel independen di atas 0,05 sehingga dapat ditarik kesimpulan bahwa tidak terjadi heteroskedastisitas atau telah sesuai dengan asumsi heteroskedastisitas. Dalam hal ini, model regresi yang baik adalah tidak terjadi heterokedastisitas atau homokedastisitas (Ghozali, 2006).

\section{Pengujian Hipotesis}

\section{Analisis Regresi Berganda}

Tahap berikutnya sesudah melakukan uji asumsi klasik adalah mengevaluasi dan menginterpretasikan model regresi berganda.

\section{Uji Koefisien Determinasi}

Berdasarkan tabel 1014 dapat dijelaskan bahwa besarnya adjusted $R^{2}$ dalam penelitian ini adalah sebesar 0,618 . Hal ini dapat diartikan bahwa $61,8 \%$ variasi kinerja auditor dapat diterangkan oleh variasi dari semua variabel independen yang ada yaitu kompetensi, independensi, dan motivasi sedangkan sisanya sebesar $38,2 \%$ dapat diterangkan oleh faktor-faktor lain yang belum dimasukkan di dalam model tersebut.

\section{Uji Simultan (Uji F)}

Sesuai dengan tabel 15 dapat diketahui bahwa tingkat signifikansi dalam Uji $\mathrm{F}$ adalah di bawah 0,05 yaitu dengan probabilitas sebesar 0,000 dan nilai $\mathrm{F}_{\text {hitung }}$ sebesar 21,530. Hasil statistik tersebut dapat diinterpretasikan bahwa kompetensi, independensi, dan motivasi memengaruhi kinerja auditor inspektorat secara simultan.

\section{Uji Parsial (Uji t)}

Tabel 16 dapat diinterpretasikan bahwa nilai koefisien regresi untuk variabel kompetensi auditor inspektorat $\left(\mathrm{X}_{1}\right)$ adalah 0,234 dengan $\mathrm{t}_{\text {hitung }}$ sebesar 2,764. Oleh karena nilai signifikansi pada variabel kompetensi kurang dari 0,05 yaitu sebesar 0,009 maka dapat ditarik kesimpulan bahwa hipotesis pertama diterima yaitu kompetensi berpengaruh positif terhadap kinerja auditor pemerintah.

Untuk nilai koefisien regresi pada variabel independensi auditor inspektorat $\left(\mathrm{X}_{2}\right)$ adalah 0,280 dengan nilai $\mathrm{t}_{\text {hitung }}$ sebesar 2,329. Selain itu, tingkat signifikansi

\begin{tabular}{lccccc}
\hline \multicolumn{1}{c}{ Model } & \multicolumn{2}{c}{$\begin{array}{c}\text { Unstandardized } \\
\text { Coefficients } \\
\text { Std. Error }\end{array}$} & $\begin{array}{c}\text { Standardized } \\
\text { Coefficients } \\
\text { Beta }\end{array}$ & T & Sig. \\
\hline B (Constant) & $-2,922$ & 1,492 & & $-1,958$ &, 058 \\
Kompetensi &, 072 &, 047 &, 303 & 1,542 &, 132 \\
Independensi &,- 040 &, 066 &,- 135 &,- 607 &, 548 \\
Motivasi &, 126 &, 096 &, 263 & 1,310 &, 199 \\
\hline
\end{tabular}

\begin{tabular}{ccccc}
\hline Model & $\mathrm{R}$ & $\boldsymbol{R}$ Square & Adjusted $R$ Square & $\begin{array}{c}\text { Std. Error of } \\
\text { the Estimate }\end{array}$ \\
\hline 1 &, $805^{\mathrm{a}}$ &, 649 &, 618 & 1,1701 \\
\hline
\end{tabular}

\begin{tabular}{cccccc}
\hline Model & Sum of Squares & Df & Mean Square & F & Sig. \\
\hline 1 Regression & 88,437 & 3 & 29,479 & 21,530 &, $000^{\mathrm{b}}$ \\
Residual & 47,922 & 35 & 1,369 & & \\
Total & 136,359 & 38 & & & \\
\hline
\end{tabular}


Kompetensi, Independensi, dan Motivasi... 48

Tabel 16. Hasil Uji Parsial (Uji t)

\begin{tabular}{|c|c|c|c|c|c|}
\hline \multirow[t]{2}{*}{ Model } & \multicolumn{2}{|c|}{$\begin{array}{c}\text { Unstandardized } \\
\text { Coefficients }\end{array}$} & \multirow{2}{*}{$\begin{array}{c}\text { Standardized } \\
\text { Coefficients } \\
\text { Beta }\end{array}$} & \multirow[t]{2}{*}{$\mathrm{T}$} & \multirow[t]{2}{*}{ Sig. } \\
\hline & B & Std. Error & & & \\
\hline 1 (Constant) & ,743 & 2,713 & & ,274 & ,786 \\
\hline Kompetensi & ,234 & ,085 & ,351 & 2,764 & ,009 \\
\hline Independensi & 280 &, 120 & ,334 & 2,329 &, 026 \\
\hline Motivasi & ,362 & ,175 & ,269 & 2,072 & ,046 \\
\hline
\end{tabular}

0,026 < tingkat signifikansi 0,05 maka $_{2}$ diterima atau dapat diartikan bahwa independensi berpengaruh positif terhadap kinerja auditor.

Terkait hipotesis ketiga $\left(\mathrm{H}_{3}\right)$ dapat dilihat bahwa nilai koefisien regresi pada variabel motivasi auditor inspektorat $\left(\mathrm{X}_{3}\right)$ adalah 0,362 dengan nilai $\mathrm{t}_{\text {hitung }}$ sebesar 2,072. Selain itu, tingkat signifikansi pada $\mathrm{X}_{3}$ adalah 0,046 hal ini menunjukkan bahwa tingkat signifikansi $0,046<$ tingkat signifikansi 0,05 maka $_{3}$ diterima atau dapat diinterpretasikan bahwa motivasi berpengaruh positif terhadap kinerja auditor.

\section{Pembahasan}

Studi ini bertujuan untuk mengetahui pengaruh kompetensi, independensi, dan motivasi terhadap kinerja auditor inspektorat daerah di Kabupaten Klaten.

\section{Hasil Pengujian Pengaruh Kompetensi terhadap Kinerja Auditor}

Hasil pengujian pengaruh kompetensi terhadap kinerja auditor menunjukkan koefisien regresi sebesar 0,234 dengan probabilitas signifikansi 0,009 kurang dari 0,05 yang berarti signifikan pada $\alpha=0,05$. Hal ini mengindikasikan bahwa hipotesis $1\left(\mathrm{H}_{1}\right)$ yang menyatakan bahwa kompetensi berpengaruh positif terhadap kinerja auditor diterima. Oleh karena itu, hasil penelitian ini mendukung penelitian yang dilakukan oleh Efendy (2010). Namun demikian, hasil penelitian ini tidak sejalan dengan hasil penelitian yang dilakukan oleh Salju dkk. (2014) yang menyatakan bahwa kompetensi tidak memengaruhi kinerja auditor pemerintah daerah secara signifikan. Penelitian ini menunjukkan bahwa kompetensi merupakan komponen yang wajib dimiliki oleh seorang auditor untuk menjalankan perannya secara profesional. Hal ini dikarenakan auditor yang mempunyai kompetensi di bidangnya akan mampu berpikir kritis, intuitif, serta berani mengambil risiko dengan penuh pertimbangan sehingga akan memberikan solusi yang terbaik dari permasalahan yang ada. Berdasarkan teori harapan, kompetensi merupakan penyebab internal yang memengaruhi kinerja auditor pemerintah untuk dapat menjalankan perannya secara optimal sebagai penjamin kualitas dalam menyelenggarakan pemerintahan yang semakin baik. Selain itu, auditor yang berkompeten akan memiliki kemauan dan kemampuan yang cepat dalam mengatasi permasalahan kerja yang dihadapi, melakukan pekerjaan dengan tenang dan penuh percaya diri, memandang pekerjaan sebagai suatu kewajiban, dan terbuka untuk meningkatkan kualitas diri melalui proses pembelajaran (Sujana, 2012). Oleh karena itu, jika auditor memiliki kompetensi yang tinggi, maka kinerja yang akan dicapai oleh auditor juga akan semakin baik.

\section{Hasil Pengujian Pengaruh Independensi terhadap Kinerja Auditor}

Hasil pengujian pengaruh independensi terhadap kinerja auditor menunjukkan koefisien regresi sebesar 0,280 dengan probabilitas signifikansi 0,026 kurang dari 0,05 yang berarti signifikan pada $\alpha=0,05$. Hal ini mengindikasikan bahwa hipotesis $2\left(\mathrm{H}_{2}\right)$ yang menyatakan bahwa independensi berpengaruh positif terhadap kinerja auditor diterima. Oleh karena itu, hasil penelitian ini mendukung penelitian yang dilakukan oleh Arifah (2012). Namun demikian, hasil penelitian 

membentuk integritas pribadi yang tinggi (Arifah, 2012). Menurut teori harapan, independensi merupakan penyebab internal yang memengaruhi kinerja auditor untuk tidak bias dan tidak berpihak dari mulai melaksanakan pemeriksaan sampai melaporkan hasil audit. Dalam hal ini seorang auditor harus bebas dari intervensi pihak manapun karena dengan adanya sikap independensi tersebut maka laporan audit yang dihasilkan akan menunjukkan kondisi yang sesungguhnya sehingga dapat digunakan dalam mengambil keputusan yang rasional. Oleh karena itu, apabila independensi auditor tinggi maka kinerjanya juga akan semakin baik.

\section{Hasil Pengujian Pengaruh Motivasi terhadap Kinerja Auditor}

Hasil pengujian pengaruh motivasi terhadap kinerja auditor menunjukkan koefisien regresi sebesar 0,362 dengan probabilitas signifikansi 0,046 kurang dari 0,05 yang berarti signifikan pada $\alpha=0,05$. Hal ini mengindikasikan bahwa hipotesis $3\left(\mathrm{H}_{3}\right)$ yang menyatakan bahwa motivasi berpengaruh positif terhadap kinerja auditor diterima. Oleh karena itu, hasil penelitian ini mendukung penelitian yang dilakukan oleh Respatiningsih dan Sudirjo (2015). Namun demikian, hasil penelitian ini berlawanan dengan hasil penelitian yang dilakukan oleh Brahmasari dan Suprayetno (2008) yang menunjukkan bahwa motivasi tidak memengaruhi kinerja perusahaan secara signifikan. Hasil penelitian ini dapat dijelaskan bahwa motivasi dapat menjadikan seseorang memiliki hasrat yang kuat dalam mengambil keputusan dan melakukan tindakan kerja untuk mencapai tujuan yang telah ditetapkan dalam suatu organisasi (Brahmasari dan Suprayetno, 2008). Berdasarkan teori harapan, motivasi merupakan penyebab internal yang memengaruhi kinerja auditor untuk dapat mengerjakan audit dengan penuh tanggung jawab. Oleh karena itu, semakin tinggi motivasi seorang auditor maka akan menciptakan semangat dan dedikasi yang tinggi dalam pekerjaannya sehingga kinerjanya juga akan semakin baik.

\section{SIMPULAN}

Menurut hasil penelitian yang telah dianalisis menggunakan SPSS 21.0 dengan sampel penelitian sebanyak 39 auditor internal pemerintah di Inspektorat Kabupaten Klaten maka kesimpulan dalam penelitian ini adalah kompetensi, independensi, dan motivasi secara parsial berpengaruh positif dan signifikan terhadap kinerja auditor pemerintah daerah. Selain itu, pengujian secara simultan (uji F) juga mengemukakan hasil bahwa kompetensi, independensi, dan motivasi berpengaruh secara simultan terhadap kinerja auditor pemerintah daerah. Nilai koefisien adjusted $R^{2}$ adalah 0,618, hal ini menunjukkan bahwa $61,8 \%$ kinerja auditor dapat dipengaruhi oleh ketiga variabel independen yaitu kompetensi, independensi, dan motivasi sedangkan sisanya $38,2 \%$ dipengaruhi oleh variabel lain yang tidak dimasukkan dalam penelitian ini.

\section{Keterbatasan dan Saran}

Penelitian ini juga memiliki beberapa keterbatasan di antaranya adalah belum memasukkan seluruh variabel yang diperkirakan dapat memengaruhi kinerja auditor. Penelitian selanjutnya diharapkan dapat menambahkan variabel lain yang diduga memengaruhi kinerja auditor, misalnya gaya kepemimpinan ketua tim, akuntabilitas, komitmen, dan integritas sehingga dapat memberikan gambaran yang lebih komprehensif terkait faktor-faktor yang memengaruhi kinerja auditor. Selain itu, dalam penelitian ini penulis menggunakan kuesioner dalam mengukur 
Kompetensi, Independensi, dan Motivasi... 50

kinerja pada setiap individual auditor yang mengakibatkan perspektif yang kurang objektif. Oleh karena itu, untuk penelitian selanjutnya diharapkan untuk mengukur variabel kinerja auditor dengan menyebarkan kuesioner dan meminta keterangan terkait kinerja auditor terhadap pihak lain yang memiliki kedudukan yang lebih tinggi dalam suatu organisasi tersebut. Untuk itu, ketua tim diminta untuk menilai kinerja setiap auditor yang tergabung di dalam timnya kemudian ketua tim itu sendiri akan dinilai kinerjanya oleh pengendali teknis selanjutnya pengendali teknis akan dinilai kinerjanya oleh pengendali mutu. Dengan adanya penilaian yang bersumber dari pihak atasan tersebut maka hasil yang diperoleh dapat lebih objektif dan mencerminkan kinerja yang sesungguhnya.

\section{Implikasi}

Penelitian ini juga memiliki implikasi terhadap kebijakan atau regulasi di Kabupaten Klaten yaitu sebaiknya pemerintah daerah terus meningkatkan kompetensi, independensi, dan motivasi auditor dalam rangka peningkatan kinerja auditor pemerintah daerah. Hal ini dapat dilakukan dengan cara memberikan pelatihan kepada auditor, memberikan keleluasaan dalam pemeriksaan atau tidak ada pembatasan ruang lingkup pemeriksaan, serta memberikan insentif secara materiil maupun non materiil sebagai motivasi bagi auditor untuk meningkatkan kinerjanya sebagai pengawas dan pemeriksa keuangan di daerah. Hal ini dikarenakan auditor internal merupakan bagian penting dalam sistem akuntabilitas pengelolaan keuangan daerah yang harus berperan nyata untuk memberikan jasa assurance and consulting dalam menjalankan peran dan fungsinya sebagai auditor. Selain itu, keterlibatan auditor internal selama proses pelaksanaan kegiatan menjadi sangat penting dikarenakan auditor berperan untuk dapat menilai risikorisiko yang mungkin terjadi sehingga dapat memberikan saran perbaikan demi tercapainya tujuan penyelenggaraan pemerintah di daerah. Oleh karena itu, auditor internal menjadi kunci keberhasilan ataupun kegagalan bagi pemerintahan di daerah sehingga faktor kinerja harus terus ditingkatkan dan diperbaiki demi mewujudkan pemerintahan yang efektif, transparan, dan akuntabel.

\section{DAFTAR PUSTAKA}

Arens, Alvin A. 2008. Auditing dan Jasa Assurance : Pendekatan Terintegrasi Jilid I. Jakarta: Erlangga.

Arifah, Nurul. 2012. "Pengaruh Independensi Auditor, Komitmen Organisasi, dan Gaya Kepemimpinan terhadap Kinerja Auditor". Skripsi. Makasar: Universitas Hasanuddin.

Badan Pemeriksa Keuangan Republik Indonesia. 2017. Peraturan Badan Pemeriksa Keuangan Republik Indonesia No. 01 Tahun 2017 tentang Standar Pemeriksaan Keuangan Negara. Jakarta: Badan Pemeriksa Keuangan Republik Indonesia.

Brahmasari, I. A. dan Agus Suprayetno. 2008. "Pengaruh Motivasi Kerja, Kepemimpinan, dan Budaya Organisasi terhadap Kepuasan Kerja Karyawan serta Dampaknya pada Kinerja Perusahaan. Studi Kasus pada PT. Pei Hai International Wiratama Indonesia". Jurnal Manajemen dan Kewirausahaan, $10(2)$.

Efendy, M. Taufiq. 2010. "Pengaruh Kompetensi, Independensi, dan Motivasi Terhadap Kualitas Audit Aparat Inspektorat Dalam Pengawasan Keuangan Daerah (Studi Empiris pada Pemerintah Kota Gorontalo)". Tesis. Universitas Diponegoro.

Ghozali, Imam. 2006. Aplikasi Analisis Multivariat dengan Program SPSS. Edisi 3. Semarang: BP Undip. 
Hasibuan, Malayu S.P. 2010. Organisasi dan Motivasi Dasar Peningkatan Produktivitas. Jakarta: PT Bumi Aksara.

Jusup, Al Haryono. 2001. Auditing (Pengauditan). Buku 1. Yogyakarta: BP STIE YKPN.

Mardiasmo. 2005. Akuntansi Sektor Publik Edisi 2. Yogyakarta: Penerbit Andi.

Maslow, Abraham H. 1970. Motivation and Personality. New York: Harper \& Row Publisher.

Mulyadi. 1992. Pemeriksaan Akuntan Edisi 4. Yogyakarta: Sekolah Tingggi Ilmu Ekonomi YKPN.

Nuraini, Listiya. 2016. Pengaruh Independensi, Gaya Kepemimpinan, dan Budaya Organisasi terhadap Kinerja Auditor (Studi Empiris pada Kantor Akuntan Publik Yogyakarta dan Solo). Skripsi. Yogyakarta: Universitas Negeri Yogyakarta.

Respatiningsih, Ida dan F. Sudirjo. 2015. "Pengaruh Komitmen Organisasi, Motivasi, Kapabilitas Dan Kepuasan Kerja Terhadap Kinerja Pegawai (Studi Empirik Pada Inspektorat Kabupaten Pemalang)”. Jurnal Ilmiah UNTAG Semarang, 4(3).

Salju; Rismawati; dan M.D. Bachtiar. 2014. "Pengaruh Kompetensi dan Independensi Terhadap Kinerja Auditor Pemerintah Kabupaten Luwu Timur". Jurnal Equilibrium, 04(2).

Sapariyah, R. Ani. 2011. "Pengaruh Good Governance dan Independensi Auditor terhadap Kinerja Auditor dan Komitmen Organisasi”. Skripsi. Surakarta: STIE AUB.

Sujana, Edy. 2012. "Pengaruh Kompetensi, Motivasi, Kesesuaian Peran dan Komitmen Organisasi terhadap Kinerja Auditor Internal Inspektorat Pemerintah Kabupaten (Studi pada Kantor Inspektorat Kabupaten Badung dan Buleleng)". Jurnal Ilmiah Akuntansi dan Hunanika, 2(1).

Trisnaningsih, Sri. 2007. "Independensi Auditor dan Komitmen Organisasi Sebagai Mediasi Pengaruh Pemahaman Good Governance, Gaya Kepemimpinan dan Budaya Organisasi Terhadap Kinerja Auditor". Simposium Nasional Akuntansi $X$. Makasar: Universitas Hasanuddin.

Vroom, Victor H. 1964. Work and Motivation. New York : John Wiley \& Sons.

Widhi, S. Nugroho dan E. Setyawati. 2014. "Pengaruh Independensi, Gaya Kepemimpinan, Komitmen Organisasi, dan Pemahaman Good Governance terhadap Kinerja Auditor Pemerintah (Studi Empiris pada Kantor BPKP Perwakilan Jawa Tengah)". Jurnal Manajemen dan Bisnis, 19(01).

Yustiningsih, Yuni. 2016. "Bupati Klaten Ditangkap, Rp 2 Miliar Diduga untuk Suap Mutasi Pejabat Ikut Disita". Diambil dari www.solopos.com/2016/12/30/ bupati-klaten-ditangkap-rp2-miliar-diduga-untuk-suap-mutasi-pejabat-ikutdisita-780860 (diakses pada 1 Desember 2017). 
